\title{
Effect of Integrated Nutrient Management on Yield Attributing Characters and Yield of Rice Under Rice - Wheat Ecosystem
}

\author{
Shobhit Singh ${ }^{1 *}$, J.S. Bohra1, Y.V. Singh², Amit Kumar Upadhyay ${ }^{3}$, \\ Shiv Shanker Verma ${ }^{1}$, Pankaj Kumar Mishra ${ }^{1}$ and M. Raghuveer ${ }^{1}$ \\ ${ }^{1}$ Department of Agronomy, ${ }^{2}$ Department of Soil Science and Agricultural Chemistry, Institute of \\ Agricultural Sciences, Banaras Hindu University, Varanasi, U.P., India \\ ${ }^{3}$ Department of Soil Science and Agricultural Chemistry, JNKV, Jabalpur, M.P., India \\ *Corresponding author
}

\section{A B S T R A C T}

Keywords

Nutrient

management,

Yield attributing

and Rice - Wheat

Ecosystem.

Article Info

Accepted:

21 June 2017

Available Online:

10 July 2017
A field experiment was conducted during 2010-11 and 2011-12 on agricultural farm of Institute of agricultural Sciences, Banaras Hindu University, Varanasi to evaluate the effect of Integrated Nutrient Sources and chemical fertilizers on growth and development of rice under rice- wheat cropping system. The experimental finding indicated that the numbers of effective tillers $\mathrm{m}-2$, Panicle length, no. of panicle hill-1, no. of grains panicle1 during both the years were recorded maximum in treatment $\mathrm{T}_{6}(50 \% \mathrm{~N}$ through $\mathrm{FYM}+$ $50 \%$ RDF to rice and $100 \%$ RDF to wheat) that being at par with T7, T10 and T11 in rice and performed significantly better than other treatments. The lowest values of all the yield attributing characters was associated with control (T1). Grain and straw yield of rice were significantly highest with the application 50\% NPK through fertilizers and $50 \% \mathrm{~N}$ through FYM to rice and $100 \%$ NPK through fertilizer to wheat (T6) but in rice it did not differ significantly to T7 and T11 in 75\% NPK through first year and T7, T10 and T11 during second year of experimentation. However, grain and straw yield of both the crops were significantly lowest in control (T1) as compared to all the treatments including farmers practice (T12).

\section{Introduction}

The rice - wheat is the most dominant cropping system in Asian subtropical countries viz. China, India, Nepal, Bangladesh and Pakistan, where it is practiced in about 24 million hectares (Mahajan and Gupta, 2009).

In India too rice-wheat cropping system (RWCS) is most widely adopted system, covering over 10.5 million ha - mostly in the Indo Gangetic Plains.
Among cereals, rice and wheat are the most important crops, which account for about 60 per cent of world's human energy requirement. In India, total area under rice is 43.13 million hectares and that of wheat is 29.57 million hectares with production of 100.45 and 90.38 million tonnes of respectively. However, the productivity of both rice and wheat is low i.e. 2,323 and 3056 $\mathrm{kg} / \mathrm{ha}$, respectively (GOI, 2015). Rapid urbanization and industrialization the available agricultural land is shrinking. In 
addition, of this express increasing population create huge food demand in upcoming decades. Therefore, to meet this huge food demand we will have to increases in production per unit of harvested area. The combination of poor soil fertility and inadequate, unbalanced, and inefficient use of fertilizers contributes much to this problem (Yadav et al., 2000; Dwivedi et al., 2001). The imbalanced use of fertilizer has disturbed the natural equilibrium of the nutrient elements operating in the soils is being mostly applied for a long period. The studies have shown that the sustainability of this important system could only be achieved through integrated use of chemical and organic sources in a balanced manner.

\section{Materials and Methods}

Looking at the importance of rice - wheat system under irrigated ecosystem of Varanasi region, declining factor productivity and soil health, it is imperative to study the integrated use of chemical fertilizers and organic sources in rice- wheat system on long term basis. Therefore, with these facts in view present study conducted during 2010-11 and 2011-12. The geographical situation of the experiment lies in the Northern Gangetic Alluvial plain at $25^{\circ} 18^{\prime}$ North latitudes, $83^{\circ} 03^{\prime}$ East longitude and at an altitude of 128.93 meters above the mean sea level. The experimental soil is sandy loam in texture with varying $\mathrm{pH} 7.72$ to 7.78 , bulk density 1.39 to $1.56 \mathrm{~g} \mathrm{cc}^{-1}$ as well as 146 to $221,10.5$ to 20.84 and 152 to $206 \mathrm{~kg} \mathrm{ha}^{-1} \mathrm{~N}, \mathrm{P}$, and $\mathrm{K}$, respectively. There were 12 treatments comprising 5 purely inorganic Viz. 50\% RDF to both rice and wheat $\left(\mathrm{T}_{2}\right), 50 \% \mathrm{RDF}$ to rice and $100 \% \mathrm{RDF}$ to Wheat $\left(\mathrm{T}_{3}\right), 75 \% \mathrm{RDF}$ to both rice and wheat $\left(\mathrm{T}_{4}\right), 100 \% \mathrm{RDF}\left(120 \mathrm{~kg} \mathrm{~N}+60 \mathrm{~kg} \mathrm{P}_{2} \mathrm{O}_{5}\right.$ $\left.+60 \mathrm{~kg} \mathrm{~K}_{2} \mathrm{O} \mathrm{ha}{ }^{-1}\right)$ both rice and wheat $\left(\mathrm{T}_{5}\right)$ and farmer's practice with $(80 \mathrm{~kg} \mathrm{~N}+40 \mathrm{~kg}$ $\left.\mathrm{P}_{2} \mathrm{O}_{5}+20 \mathrm{~kg} \mathrm{~K}_{2} \mathrm{O} \mathrm{ha}^{-1}\right)\left(\mathrm{T}_{12}\right)$ to both rice and wheat. Six treatment are integrated integration of inorganic and organic sources i.e. $\left(\mathrm{T}_{6}\right) 50 \%$
$\mathrm{RDF}+50 \% \mathrm{~N}$ through $\mathrm{FYM}$ to rice and $100 \% \mathrm{RDF}$ to wheat, $\left(\mathrm{T}_{7}\right) 75 \% \mathrm{RDF}+25 \% \mathrm{~N}$ through FYM for rice and $75 \%$ RDF to wheat, $\left(\mathrm{T}_{8}\right) 50 \% \mathrm{RDF}+50 \% \mathrm{~N}$ through crop residue to rice and $100 \% \mathrm{RDF}$ to wheat, $\left(\mathrm{T}_{9}\right) 75 \%$ $\mathrm{RDF}+25 \% \mathrm{~N}$ through crop residue to rice and $75 \% \mathrm{RDF}$ to wheat, $\left(\mathrm{T}_{10}\right) 50 \% \mathrm{RDF}+$ $50 \% \mathrm{~N}$ through green leaf manuring to rice and $100 \%$ RDF to wheat, $\left(\mathrm{T}_{11}\right) 75 \% \mathrm{RDF}+$ $25 \% \mathrm{~N}$ through green leaf manuring to rice and $75 \%$ RDF to wheat, along with one control having no nutrient nutrition application in either of the season $\left(\mathrm{T}_{1}\right)$. Rice variety HUR-105 and wheat variety HUW234 were selected for the study. The treatments (12) were arranged in randomized block design with 4 replications. Plot size was kept $11 \times 6 \mathrm{~m}^{2}$ (gross) and $10 \times 5 \mathrm{~m}^{2}$ (net) with $1 \mathrm{~m}$ plot border.

The observations on growth characters viz. plant height, LAI and SPAD value, dry matter accumulation, number of green leaves and number of tillers per hill for rice were recorded at 30, 60, 90 DAT and at harvest, and

\section{Yield attributing characters}

\section{Effective tiller $\mathbf{m}^{-2}$}

A close analysis of the data presented in table 1 clearly showed marked effect of various treatments on the effective tiller $\mathrm{m}^{-2}$. Marked reduction in effective tiller $\mathrm{m}^{-2}$ was observed with decreasing levels of fertilizer application from $\mathrm{T}_{5}(100 \% \mathrm{RDF}$ to both rice and wheat) to control $\left(\mathrm{T}_{1}\right)$. Though, $\mathrm{T}_{5}$ remained comparable to $\mathrm{T}_{4}, \mathrm{~T}_{3}$ and $\mathrm{T}_{12}$ proved significantly superior to $\mathrm{T}_{2}$ and $\mathrm{T}_{1}$ in both the years. Substitution of $50 \% \mathrm{~N}$ through FYM + $50 \% \mathrm{RDF}$ to rice and $100 \% \mathrm{RDF}$ to wheat $\left(\mathrm{T}_{6}\right)$ produced maximum number of tiller $\mathrm{m}^{-2}$. Though, $\mathrm{T}_{6}$ remained at par with $\mathrm{T}_{5}(100 \%$ $\mathrm{RDF}$ to both the crops), $\mathrm{T}_{7}(75 \% \mathrm{RDF}+25 \%$ $\mathrm{N}$ through FYM to rice and $75 \% \mathrm{RDF}$ to 
wheat $), \mathrm{T}_{10}(50 \% \mathrm{RDF}+50 \% \mathrm{~N}$ through green manure to rice and $100 \% \mathrm{RDF}$ to wheat) and $\mathrm{T}_{11}(75 \% \mathrm{RDF}+25 \% \mathrm{~N}$ through green manure to rice and $75 \% \mathrm{RDF}$ to wheat) produced significantly higher number of effective tiller $\mathrm{m}^{-2}$ than all other inorganic and INM treatments.

\section{Panicle length}

It is apparent from table 1 that panicle length decreased markedly with the curtailment of fertilizer doses from $100 \% \mathrm{RDF}\left(\mathrm{T}_{5}\right)$ to control. Being at par with $\mathrm{T}_{4}(75 \% \mathrm{RDF}$ to both rice and wheat), $\mathrm{T}_{5}$ recorded significantly higher panicle length than lower doses of inorganic nutrient application $\left(\mathrm{T}_{12}\right.$, $\mathrm{T}_{3}, \mathrm{~T}_{2}$, and $\mathrm{T}_{1}$ ).

The panicle length was highest in $\mathrm{T}_{6}(50 \%$ RDF through fertilizers $+50 \% \mathrm{~N}$ through FYM to rice and $100 \%$ NPK through fertilizers to wheat) during both the years. Though, it did not show significant differences over $75 \% \mathrm{RDF}+25 \% \mathrm{~N}$ through FYM to rice and $75 \% \mathrm{RDF}$ to wheat $\left(\mathrm{T}_{7}\right)$, $50 \% \mathrm{RDF}+50 \% \mathrm{~N}$ through $\mathrm{GM}$ to rice and $100 \% \mathrm{RDF}$ to wheat $\left(\mathrm{T}_{10}\right), 75 \% \mathrm{RDF}+25 \%$ $\mathrm{N}$ through GM to rice and $75 \% \mathrm{RDF}$ to wheat $\left(\mathrm{T}_{11}\right)$ and $100 \%$ RDF to both rice and wheat $\left(\mathrm{T}_{5}\right)$ produced significantly longer panicle than $(50 \% \mathrm{RDF}+50 \% \mathrm{~N}$ through wheat straw to rice and $100 \% \mathrm{RDF}$ to wheat $\left(\mathrm{T}_{8}\right)$ and $75 \% \mathrm{RDF}+25 \% \mathrm{~N}$ through wheat straw to rice and $75 \% \mathrm{RDF}$ to wheat $\left(\mathrm{T}_{9}\right)$ during both the years.

\section{No. of panicle hill'}

Data on number of panicles as influenced by different levels of inorganic fertilizers and organic sources presented in table 1 revealed that number of panicles hill ${ }^{-1}$ increased with the increasing levels of fertilizer application to rice from control $\left(\mathrm{T}_{1}\right)$ to $100 \% \mathrm{RDF}$ to both rice and wheat $\left(\mathrm{T}_{5}\right)$ during both the years.
Number of panicle hill $^{-1}$ was maximum in treatment where $50 \%$ NPK was applied through fertilizer and 50\% $\mathrm{N}$ through FYM to rice accompanied with $100 \%$ NPK to wheat $\left(\mathrm{T}_{6}\right)$. However, it did not produce significant difference from $\left(\mathrm{T}_{7}\right) 75 \% \mathrm{RDF}+25 \% \mathrm{~N}$ through FYM to rice and $75 \%$ RDF to wheat, $\left(\mathrm{T}_{10}\right) 50 \% \mathrm{RDF}+50 \% \mathrm{~N}$ through GM to rice and $100 \%$ RDF to wheat, $\left(\mathrm{T}_{11}\right) 75 \% \mathrm{RDF}+$ $25 \% \mathrm{~N}$ through GM to rice and $75 \% \mathrm{RDF}$ to wheat. The Farmer's practice of fertilization $\left(\mathrm{T}_{12}\right)$ though remained at par to $\mathrm{T}_{2}$, produced significantly higher number of paniclehill ${ }^{-1}$ over control $\left(\mathrm{T}_{1}\right)$ during both the years.

\section{No. of grains panicle ${ }^{-1}$}

It can be seen from 1 that average number of grains per panicle reduced with decreasing level of fertilizers from $100 \%$ RDF to both rice and wheat $\left(\mathrm{T}_{5}\right)$ to control $\left(\mathrm{T}_{1}\right)$. The no. of grain panicle ${ }^{-1}$ was maximum in $\mathrm{T}_{6}(50 \%$ $\mathrm{RDF}+50 \% \mathrm{~N}$ through FYM to rice and $100 \%$ RDF to wheat) and being comparable to by $75 \% \mathrm{RDF}+25 \% \mathrm{~N}$ through $\mathrm{FYM}$ to rice and $75 \% \mathrm{RDF}$ to wheat $\left(\mathrm{T}_{7}\right), 50 \% \mathrm{RDF}+$ $50 \% \mathrm{~N}$ through GM to rice and $100 \% \mathrm{RDF}$ to wheat $\left(\mathrm{T}_{10}\right), 75 \% \mathrm{RDF}+25 \% \mathrm{~N}$ through $\mathrm{GM}$ to rice and $75 \% \mathrm{RDF}$ to wheat $\left(\mathrm{T}_{11}\right)$, it proved distinctly superior to other treatments.

\section{Test weight (g)}

It is apparent from table 1 that 1000 grain weight declined with decreasing levels of fertilizer application from $\mathrm{T}_{5}(100 \%$ RDF to both rice and wheat) to $\mathrm{T}_{1}$ (control) but the differences were significant only between the highest and lowest levels during both the years. The maximum1000-grain weight was found associated with highest in $\mathrm{T}_{6}(50 \%$ $\mathrm{RDF}+50 \% \mathrm{~N}$ through FYM to rice $+100 \%$ $\mathrm{RDF}$ to wheat) and being at par with $\mathrm{T}_{7}(75 \%$ $\mathrm{RDF}+25 \% \mathrm{~N}$ through FYM to rice and $75 \%$ $\mathrm{RDF}$ to wheat), it proved distinctly superior to other treatments during both the years. 


\section{Yield of rice}

Data on grain and straw yield of rice for the years 2010 and 2011 as influenced by long term treatments of NPK have been presented in table 2 .

\section{Grain yield}

The rice grain yield increased with increasing levels of fertilizer doses from control $\left(\mathrm{T}_{1}\right)$ to $100 \%$ RDF to both rice and wheat $\left(\mathrm{T}_{5}\right)$ during both the years. The highest grain yield was recorded in $\mathrm{T}_{6}(50 \% \mathrm{RDF}+50 \% \mathrm{~N}$ through FYM to rice and $100 \%$ RDF to wheat) and being at par $\mathrm{T}_{7}(75 \% \mathrm{RDF}+25 \% \mathrm{~N}$ through FYM to rice and $75 \%$ RDF to wheat) in both the years and $\mathrm{T}_{10}(50 \% \mathrm{RDF}+50 \% \mathrm{~N}$ through $\mathrm{GM}$ to rice and $100 \% \mathrm{RDF}$ to wheat) and $\mathrm{T}_{11}$ (75\% RDF $+25 \% \mathrm{~N}$ through GM to rice and $75 \%$ RDF to wheat in 2011 produced significantly higher grain yield than rest of the treatments. As compared to $\mathrm{T}_{5}$ INM treatments $\mathrm{T}_{6}$ produced $7.2 \%$ and $9.3 \%$ higher grain yield during 2010 and 2011 respectively. In control $\left(\mathrm{T}_{1}\right)$ plots, rice grain yield was significantly lower than all other treatments. Farmer's practice $\left(\mathrm{T}_{12}\right)$, also exhibited distinctly superior over $\mathrm{T}_{2}$ and control $\left(\mathrm{T}_{1}\right)$.

\section{Straw yield}

Data presented in table 2 revealed marked reduction in straw yield with decreasing levels of fertilizer application from $\mathrm{T}_{5}(100 \%$ RDF to both rice and wheat) to control $\left(\mathrm{T}_{1}\right)$. Further, it was observed that the straw yield was highest in $\mathrm{T}_{6}(50 \% \mathrm{RDF}+50 \% \mathrm{~N}$ through FYM to rice and $100 \%$ RDF to Wheat), though it remained comparable to $\mathrm{T}_{7}$ $(75 \% \mathrm{RDF}+25 \% \mathrm{~N}$ through FYM to rice and $75 \% \mathrm{RDF}$ to Wheat and $\mathrm{T}_{5}(100 \% \mathrm{RDF}$ to both rice and wheat) in both the years, $\mathrm{T}_{11}$ $(75 \% \mathrm{RDF}+25 \% \mathrm{~N}$ through GM to rice and $75 \% \mathrm{RDF}$ to wheat) and $\mathrm{T}_{10}(50 \% \mathrm{RDF}+$
$50 \% \mathrm{~N}$ through GM to rice and $100 \% \mathrm{RDF}$ to wheat) in 2010, proved distinctly superior to other treatments.

\section{Harvest index}

Data showed in table 2 clearly indicated that the harvest index of rice did not influence markedly under various treatments performed better than treatments supplying nutrients through fertilizers and control. The highest harvest index was recorded in treatments $\mathrm{T}_{9}$ during first year and $\mathrm{T}_{10}$ during second year and the lowest harvest index was found associated with $\mathrm{T}_{1}$ (control) in both the year. However, the difference were failed to touch the level of significance.

\section{Results and Discussion}

The effect of different integrated nutrient management (INM) treatments and fertility levels was observed on various yield attributes and yields. Well-nourished plants with higher amounts of fertilization increased the number of effective tillers, the most important yield contributing characters of rice and wheat and is straightway governed by the number of shoots, their growth and development.

Yield contributing characters, spike length, number of shoots/tillers $\mathrm{m}^{-2}$, like number of panicles or spikes per unit, test weight and filled grain increased significantly in plots where 50\% NPK through fertilizers $+50 \% \mathrm{~N}$ through FYM to rice and $100 \%$ NPK through fertilizers to wheat (T6) was applied, since addition of organic manures (FYM) and Wellnourished plants with higher amounts of fertilization increased the number of spikelet per panicle/grains per spike. Spikelet fertility percentage was also significantly influenced by the rate of fertilization during both the crop seasons. 
Table.1 Effect of Integrated Nutrient Management on yield attributes of rice

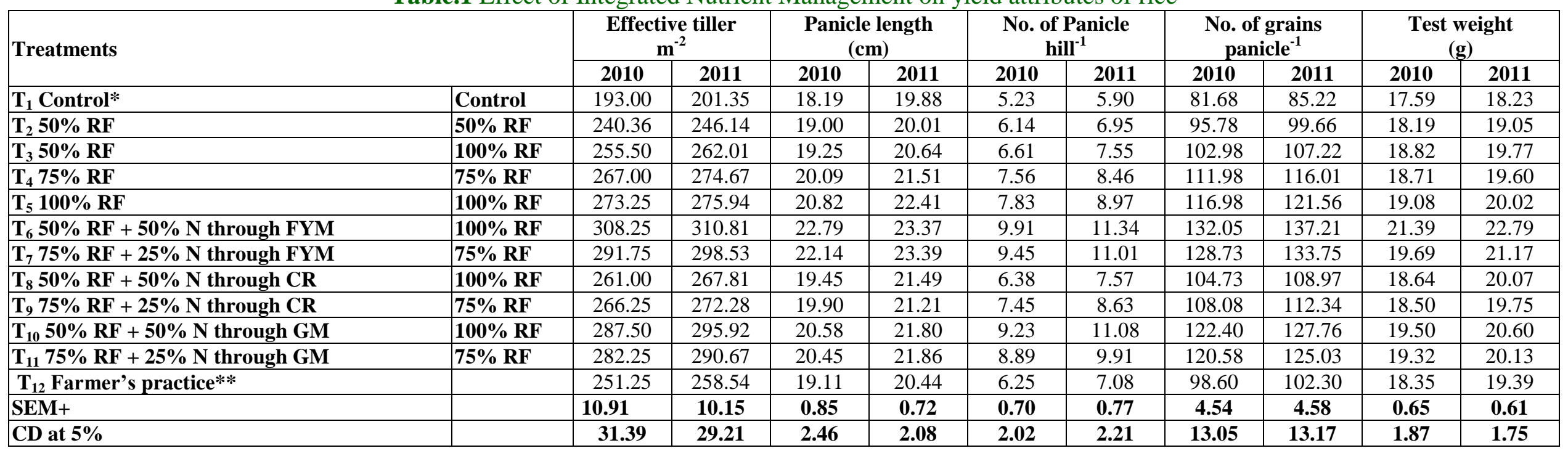

Table.2 Effect of Integrated Nutrient Management on yield of rice

\begin{tabular}{|c|c|c|c|c|c|c|c|}
\hline \multicolumn{2}{|l|}{ Treatments } & \multicolumn{2}{|c|}{$\begin{array}{c}\text { Grain yield } \\
\text { qha }^{-1}\end{array}$} & \multicolumn{2}{|c|}{$\begin{array}{c}\text { Straw yield } \\
\text { qha }^{-1}\end{array}$} & \multicolumn{2}{|c|}{ Harvest Index } \\
\hline & & 2010 & 2011 & 2010 & 2011 & 2010 & 2011 \\
\hline $\mathbf{T}_{1}$ Control* & Control & 26.70 & 25.55 & 38.65 & 42.85 & 40.91 & 37.38 \\
\hline $\mathbf{T}_{2} \mathbf{5 0 \%} \mathbf{R F}$ & $50 \%$ RF & 42.15 & 42.48 & 58.05 & 66.04 & 42.12 & 39.25 \\
\hline $\mathbf{T}_{3} \mathbf{5 0 \%} \mathbf{R F}$ & $100 \%$ RF & 42.75 & 44.12 & $\mathbf{5 7 . 8 5}$ & $\mathbf{7 0 . 8 0}$ & 42.59 & 38.38 \\
\hline $\mathrm{T}_{4} \mathbf{7 5 \%} \mathrm{RF}$ & $75 \%$ RF & 47.30 & 48.71 & 62.65 & 75.54 & 43.01 & 39.25 \\
\hline $\mathrm{T}_{5} \mathbf{1 0 0 \%} \mathrm{RF}$ & $100 \%$ RF & 49.80 & 50.79 & 69.40 & 80.31 & 41.78 & 38.75 \\
\hline $\mathrm{T}_{6} 50 \% \mathrm{RF}+50 \% \mathrm{~N}$ through FYM & $100 \%$ RF & 53.40 & 55.73 & 73.55 & 86.00 & 42.07 & 39.32 \\
\hline $\mathrm{T}_{7} 75 \% \mathrm{RF}+25 \% \mathrm{~N}$ through FYM & $75 \%$ RF & $\mathbf{5 0 . 9 5}$ & 53.49 & 72.20 & 84.15 & 41.40 & 38.89 \\
\hline $\mathrm{T}_{8} 50 \% \mathrm{RF}+50 \% \mathrm{~N}$ through CR & $100 \%$ RF & 43.00 & 44.81 & 58.10 & 73.90 & 42.60 & 37.69 \\
\hline $\mathrm{T}_{9} \mathbf{7 5 \%} \mathrm{RF}+25 \% \mathrm{~N}$ through $\mathrm{CR}$ & $75 \%$ RF & $\mathbf{4 7 . 8 5}$ & 47.57 & 60.10 & 75.85 & 44.36 & 38.57 \\
\hline $\mathrm{T}_{10} 50 \% \mathrm{RF}+\mathbf{5 0 \%} \mathrm{N}$ through GM & $100 \%$ RF & 48.65 & 53.10 & 69.95 & 79.43 & 41.07 & 40.09 \\
\hline $\mathrm{T}_{11} 75 \% \mathrm{RF}+25 \% \mathrm{~N}$ through GM & $75 \%$ RF & 51.10 & 52.11 & 71.80 & 79.05 & 41.58 & 39.76 \\
\hline $\mathbf{T}_{12}$ Farmer's practice** & & 47.38 & 45.14 & 63.80 & 69.21 & 42.64 & 39.48 \\
\hline SEM+ & & 0.94 & 1.35 & 1.78 & 2.27 & - & - \\
\hline CD at $5 \%$ & & 2.72 & 3.89 & 5.13 & 6.53 & NS & NS \\
\hline
\end{tabular}


There was a balanced increase in N, P and K levels which might have helped in improving the spikelet fertility. Individual grain weight (expressed as 1000-grain weight) was also significantly improved with the application of manures and fertilizers. The advantage of organic manures is quite obvious, as these provide a steady supply of nutrients leading better growth of plants. Moreover, the increased availability of $\mathrm{P}$ and $\mathrm{K}$ in addition to other plant nutrients released by the organic manures might have contributed in enhancing the yield-attributes. The positive impact of availability of individual plant nutrients and humic substances from manure and balanced supplement of nitrogen through inorganic fertilizers might have induced cell division, expansion of cell wall, meristematic activity, photosynthetic efficiency and regulation of water intake into the cells, resulting in the enhancement of yield parameters (Sekar, 2003). Improvement in yield due to combined application of inorganic fertilizer and organic manure might be attributed to control release of nutrients in the soil through mineralization of organic manure which might have facilitated better crop growth and yield (Katkar et al., 2011). Larijani and Hoseini (2012) also found that more tiller number (28\%), more panicle/m2 (60\%), number of filled grains/m2 (20.6\%), spikelet per panicle $(19.6 \%)$ and more grain yield $(30.6 \%)$ with combined use of organic and chemical fertilizer compared with chemical fertilizer alone.

The experimental finding indicated that the yield attributes viz: numbers of effective tillers m-2, Panicle length, no. of panicle hill1 , no. of grains panicle- 1 content and yield (grain and straw) was markedly decline with curtailment in level of chemical fertilizer from $100 \% \mathrm{RDF}$ to both rice and wheat $\left(\mathrm{T}_{5}\right)$ to control $\left(\mathrm{T}_{1}\right)$. All recorded highest value in $\mathrm{T}_{6}$ where $50 \% \mathrm{RDF}+50 \% \mathrm{~N}$ through FYM was applied to rice accompanied with $100 \% \mathrm{RDF}$ to wheat. The minimum value was observed in $\mathrm{T}_{1}$ (Control). However, harvest index did not influence with either chemical or INM treatments.

It was concluded from the result of experiment that integrated nutrient supply improved the yield attributing characters and yield of rice. Substitution of $50 \% \mathrm{~N}$ through FYM+ 50\% RDF to rice accompanied with $100 \%$ RDF to wheat was better than $\mathrm{N}$ substitution through crop residue and green manuring as well as chemical sources of nutrients.

\section{References}

Anonymous (2015), Agriculture statistics at a glance 2015, Directorate of Economics and Statistics, Department of Agriculture and Cooperation, Ministry of Agriculture, government of India: 6971

Dwivedi, B.S. Shukla, A.k. Singh, V. K. and Yadv, R. L. (2001). Development of farmers' resource-based integratedplant nutrient supply systems: experience of a FAO-ICAR-IFFCO collaborative project and AICRP on soil test crop

Katkar, R. N. Sonune, B. A. and Kadu, P. R. (2011). Long-term effect of fertilization on soil chemical and biological characteristics and productivity under sorghum (Sorghum bicolor) - wheat (Triticum aestivum) system in Vertisol. Indian Journal of Agricultural Sciences. 81(8): 734-739.

Larijani, B. A. and Hoseini, S.J. (2012). Comparison of Integrated Chemical and Organic Fertilizer Management on Rice Growth and Yield under System of Rice Intensification (SRI). International journal of Agronomy and Plant Production. Vol. 3 (S): pp.726-731.

Mahajan, A. and Gupta, R.D. (2009). The rice- wheat cropping system, integrated 
nutrient management (INM) in a sustainable rice-wheat cropping system, Springer Science, 109 -112.

Sekar, A. (2003). Studies on the evaluation of sugarcane variety and production technologies for animating sugarcane productivity in coastal region of Tamil Nadu. Ph.D. thesis, Annamalai University, Annamalainagar, Tamil Nadu.
Yadav, R. L. Dwivedi B. S. Prasad, K. Tomar O. K. Shurpali N. J. and Pandey P. S. (2000) Yield trends, and changes in soil organic-C and available NPK in a longterm rice-wheat system under integrateduse of manures and fertilisers Field Crops Research 68 (2000) 219246.

\section{How to cite this article:}

Shobhit Singh, J.S. Bohra, Y.V. Singh, Amit Kumar Upadhyay, Shiv Shanker Verma, Pankaj Kumar Mishra and Raghuveer M. 2017. Effect of Integrated Nutrient Management on Yield Attributing Characters and Yield of Rice Under Rice-Wheat Ecosystem. Int.J.Curr.Microbiol.App.Sci. 6(7): 2025-2031. doi: https://doi.org/10.20546/ijcmas.2017.607.240 